\title{
MARKET POWER ON THE COLONIAL FRONTIER? EVIDENCE FROM SÃO PAULO 1800-1840 *
}

\author{
GIOVANNI FEDERICO \\ European University Institute ${ }^{\mathrm{a}}$ \\ RICARDO PAIXAO \\ Universidade de São Paulo ${ }^{b}$
}

\begin{abstract}
Economists often assume that agricultural markets in history were competitive, and all producers received the same price. In contrast, most agricultural historians deem prices to differ among agents, according to their social status and "power». This paper tests these opposite views with a database of some 12,500 transactions for the São Paulo area in Brazil in the first decades of the $19^{\text {th }}$ century. Prices received by farmers were positively related to total sales, a proxy for the size of the estate, and also to the share on the relevant market, which measures the market power. These results are consistent with the anecdotal evidence about the growing importance of large slave estates which, however, did not wipe out small household farms.
\end{abstract}

Keywords: market power, agricultural prices, early $19^{\text {th }}$ century, Brazil JEL Classification: D40, N56, Q13

\section{RESUMEN}

Los economistas asumen que los mercados agrícolas a lo largo de la historia son competitivos y todos los productores reciben el mismo precio. En

* Received 12/21/2007. Accepted 03/02/2009.

a Department of History and Civilization. European University Institute. Giovanni.Federico@eui.eu.

b Universidade de São Paulo. rfp@usp.br. 
contraste, la mayoría de los historiadores agrícolas consideran que los precios difieren entre agentes en relación a su poder y estatus social. Este papel examina estos puntos de vista opuestos a partir de una base de datos de 12.500 transacciones para el área de São Paulo en Brasil en las primeras décadas del siglo XIX. Los precios recibidos por los agricultores estuvieron positivamente relacionados con las ventas, una proxy del tamaño de la hacienda y también con la cuota de mercado principal (una aproximación al poder de mercado). Estos resultados son consistentes con la evidencia cualitativa acerca de la importancia creciente de los grandes estados esclavistas sin dejar fuera de la explicación a los pequeños granjeros.

Palabras clave: poder de mercado, precios agrícolas, siglo XIX, Brasil

\section{INTRODUCTION}

The development of markets is reckoned to be, jointly with technological change, the main driving force of economic growth. Market integration has duly attracted much attention from economic historians in recent years (Jacks 2006, Shiue and Keller 2007, Bateman 2007, O'Rourke and Findlay 2007, Studer 2008). The literature deals almost exclusively with the longrange convergence of prices in main cities and the efficiency of national and international markets. In fact the data on rural and local markets, where ultimately most transactions were conducted, are extremely scarce. The missing empirical evidence is often substituted by a priori statements. Economic historians and development economists often assume that agricultural markets were efficient and competitive. In contrast, most agricultural historians believe that local markets for agricultural products were dominated by merchants and major landowners. Imperfect competition and market-rigging were not only socially unfair, but also harmful to long run economic growth to the extent that they discouraged small producers from producing for the market, and thus reduced the overall benefits specialization and commercialization.

These two views yield testable hypotheses about the formation of prices (Section 2). The economists' view of a competitive market implies that all producers get the same price. The alternative hypothesis suggests that prices depended on wealth and social status of the parts - so that major landowners received more for the same goods. Unfortunately, data on prices received by individual farmers are extremely difficult to find. Rothemberg (1992) has had to collect them painstakingly from the account books of Massachusetts farmers. This paper uses another felicitous exception to the dearth of data, the $19^{\text {th }}$ century population censuses of the Capitania (captaincy) of São Paulo. Section Three sketches out briefly the transformation of the area from a thinly populated frontier to a substantial agricultural pro- 
ducer (Vidal Luna and Klein, 2003a). Section Four reports the key information about the data-base and the variables. Section Five highlights the main facts, while Section Six reports the econometric results. Section Seven concludes.

\section{HOW CAN PRICES DIFFER AMONG PRODUCERS?}

The literature on imperfect competition in agricultural markets is substantial (Sexton and Lavoie, 2001; Wohlgenant, 2001), but not terribly helpful for the case at hand. The typical model tries to prove the existence of oligopsony by large food processing industries from aggregate data on market prices and quantities. Most models assume the supply side to be perfectly competitive and the rest to be oligopolistic. No author, as far as we know, considers the possibility of differentiation among producers. Some of them might have a degree market power: as Figure 1 shows, the existence of such power would cause prices to differ among producers even for a homogenous good.

FIGURE 1

A SIMPLE MODEL OF SEGMENTED MARKETS

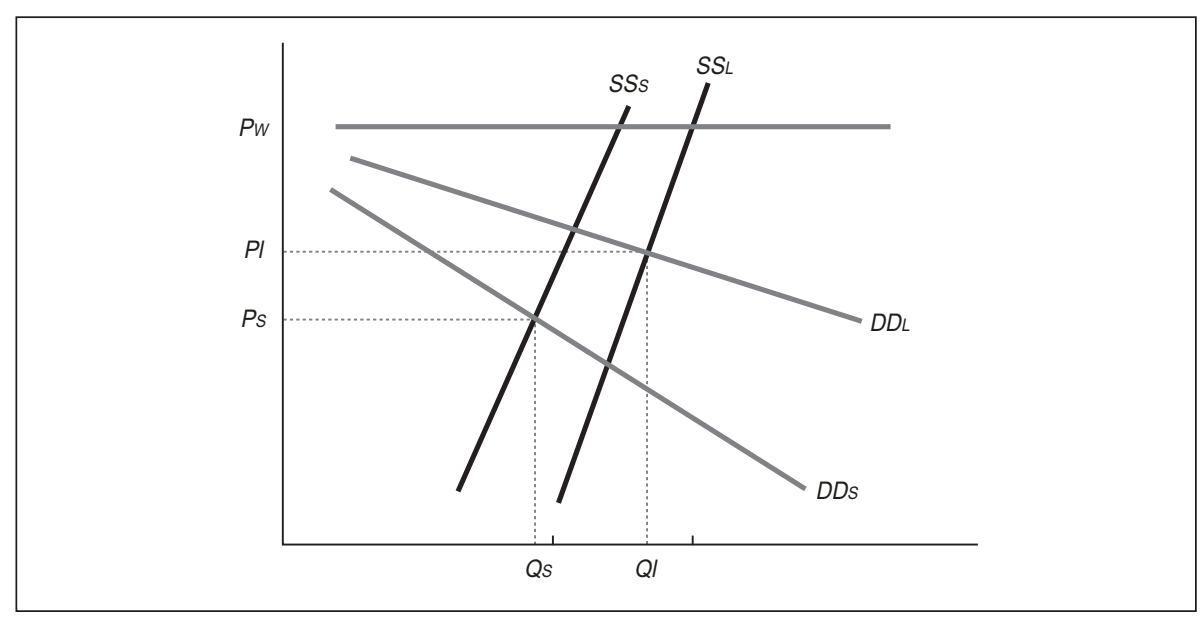

There are two groups of producers, small-scale («peasants») and large-scale ( landowners») producers, with separate supply curves (SSS and SSL). Consistently with the anecdotal evidence for the case of São Paulo, the supply for both sectors is rather inelastic and the landowners' sector is larger. Producers sell to merchants who re-sell the good on the 
«world» market. World demand is perfectly elastic at price Pw, but the derived local demand curve(s) are downward sloping because transaction costs, most notably for transportation, rise with quantity as merchants have to tap more distant markets and/or to contact marginal producers. Peasants and landowners face different demand curves (DDS and DDL). Landlords are offered higher prices, ceteris paribus, because they wield «market power». They can collude and/or use their political and administrative power to force merchants to pay a higher price ${ }^{1}$. In equilibrium, peasants sell $Q_{S}$ at price $P_{S}$ and landowners $Q_{L}$ at price $P_{L}$, with $P_{L}>P_{S}$ and the total revenue for merchants is $Q_{S}{ }^{*}\left(P_{W} P_{S}\right)+Q_{L}{ }^{*}\left(P_{W}-P_{L}\right)$. An increase (decrease) in market power shifts upward (downward) $D D_{L}$ and thus widens (shrinks) the price gap ceteris paribus. An increase in the relative size of the landowner sector (a widening of the distance between the two supply curves) ceteris paribus decreases the price gap, and viceversa.

The existence of market power is however only one possible explanation of price difference among producers. Prices might differ even in the baseline case of a perfectly efficient and competitive market with no transaction costs and no market for credit and risk-neutral agents. In this case, all sellers would get the same price for the same good at the same time in the same location. Therefore, prices would differ if any of these conditions is violated -i.e. if

a) The quality of the product differs: better products obtain higher prices, ceteris paribus.

b) The timing of the sale within the year differs. Prices may vary as a consequence of production and consumption shocks. Even without such shocks, prices should increase throughout the crop year to cover interest rates, costs of storage and risk (McCloskey-Nash 1984).

c) The location of sale differs. Farm-gate prices are lower than market ones to cover transportation costs, and the difference (the vertical distance between PW and PS or PL) is larger the further away the farm is from the market.

In terms of Figure 1, the first two factors affect the location and shape of the supply curve(s), while the location of sales could also affect the vertical distance between DDS and DDL if landlords' estates happen to cluster closer to the access to the «world» market.

1 The model as such does not make any assumption about the demand side. It is consistent with perfect competition and price-taking among merchants, but also with oligopoly. In this case, merchants could squeeze peasants (i.e. $D D_{S}$ would be higher than the perfect competition demand curve), while $D D_{L}$ and $S S_{L}$ would create a bilateral oligopoly as in Schroeter et al. (2000). The presence of two different groups of purchasers is also possible - small-scale traders who scouted around in the countryside and big merchants who made deals with large landowners in smoke-filled rooms in São Paulo. 
Introducing information, transaction costs, risk-aversion and market for credit adds four further possible causes of price differentiation among producers:

d) Duration of contract. Long-term contracts shift the risk of price fluctuations to the buyers, who, if risk-averse as usual, must be compensated with a price lower than the spot market one.

e) Access to information. Some producers might get a higher price because they have more information or because they are more skilled at exploiting common information.

f) Unit transaction costs. There might be economies of scale in transactions, which can be shared between merchants and producers.

g) The need for credit and access to it. The buyer may anticipate part of the sale proceeds to the seller, the so called interlinked transactions. In this case, the sale price is bound to be lower than the market one by the amount of the interest, and the difference is greater the higher the rate of the loan.

Causes $a$ ) to $c$ ) are, in theory, independent of the characteristics of the farm and of the agents. A poor peasant could grow the best corn in town, or be lucky to sell at the right moment of the year or decide to take his products to a distant town if he is not satisfied with prices in the nearby village. In contrast, the other possible causes of differentiation are likely to be positively related to the size of the farm. Wealthier farmers are more likely than poor peasants to have good access to information and to credit. They are more likely to be literate (or, if not, to be able to hire a literate manager), to have collateral to pledge and, also, to be trusted by merchants to sign long-term contracts.

Summing up, price differentials can reflect three different (sets of) causes - pure market power (M), size and other characteristics of the farm $(\mathbf{S})$, which determine access to information and credit, the level of transaction costs etc. [factors $e$ ) to $g$ )] and controls (X) for the quality of product, the timing of sale and so on [factors $a$ ) to $d$ )]. Their importance can be assessed by running a regression

$P_{i j}{ }^{t} / P_{i \mu}{ }^{t}=(\mathbf{M}, \mathbf{W}, \mathbf{S})$

where the dependent variable is the ratio of price received by the i-th household for the $\mathrm{j}$-th product in year t to the average for all farmers $\left(P_{i \mu}{ }^{t}\right)$ in the same village.

\section{THE DEVELOPMENT OF SÃO PAULO: A FRONTIER ECONOMY}

The early $19^{\text {th }}$ century São Paulo Capitania covered an area of some $530,000 \mathrm{~km}^{2}$ on the border with Argentina, corresponding to the present day states of São Paulo and Paraná. At the end of the $17^{\text {th }}$ century that huge area 
was populated by only 15-20,000 people, mostly Indians and mestizos (Buarque de Hollanda, 1966). Subsequently, however, the population grew rapidly - to 84,000 in $1765-68$, to 188,000 in 1803 and to 327,300 in 1836 (Marcilio, 2000). The settlement expanded from the coastal area towards the plateau in the interior - first the Paraiba Valley in the North and then the fertile areas of West Paulista inland. However, transport remained difficult and expensive. On the best roads, such as the caminho do mar, the road from São Paulo to the coast (opened in 1792), merchandise could be transported by oxen carts. But in many places goods still had to be carried by mules or porters (Prado, 1942).

Until the end of the $18^{\text {th }}$ century the Capitania had produced mainly foodstuffs (corn, rice, beans) for consumption by the local population and by the miners in neighboring Minas Gerais (Petrone, 1967). Sugar-cane had been cultivated for local consumption in the area since the $16^{\text {th }}$ century, but production for the world market was boosted by the collapse of competition from Haiti in the 1790s (Petrone, 1967). In contrast, there was no tradition of coffee growing in the area. Large-scale production started in the early decades of the $19^{\text {th }}$ century in the Paraiba Valley and slowly extended to the West Paulista after the 1850s. As early as 1836, these two products jointly accounted for about a quarter of gross output in São Paulo (coffee for 16.3 per cent and sugar for 11.6 per cent) (Müller, 1978). Anyway, most output was still for domestic consumption: the single most important product was corn (34 per cent of the output), rice accounted for 9.2 per cent of the total, pigs and cows for 6 per cent each and so on.

In most new areas, the land was cleared by squatters. They set up quasisubsistence farms, which were later substituted by more substantial productive units, often manned by imported slaves. The inflow from Africa remained high until the 1840s, some forty years after the English ban on slave trade (1807) and ten after the Portuguese ban (promulgated in 1825 and effective as of 1830). The share of slave estates (fazendas) on total output grew remarkably over the period and the increase was concentrated in the upper tail of the distribution. The average number of slaves per «engenho» (sugar-producing estate) rose from 13 in 1799 to 31 in 1829 (Vidal Luna and Klein, 2003a, tab. 2.2 and 2.3). In the "vila» of Areias, the main coffeeproducing area, slave-owning households accounted for 69 per cent of total output in 1817 and for 90 per cent in 1836 (Vidal Luna and Klein, 2003a, tab. 3.5-3.6). The share of households with more than 41 slaves grew from 9 per cent to 32 per cent, while that of households with 0 to 5 slaves declined from 32 per cent to 12 per cent. Yet São Paolo was not the West Indies. Slaves always remained a minority - around one quarter - of the total population of the whole capitania. The fazendas were decidedly smaller than the slave estates of the Caribbean, where the average number of slaves was 250. Small scale producers remained important throughout the period, especially in the production of coffee and foodstuffs. As late as 1829, about 
half of the coffee producers in the whole Capitania had no slaves. Furthermore, the fazendas were not specialized in export products: almost all of them produced food for domestic consumption by slaves and masters and also for the market. Thus, the area featured a mix of small and largescale farms with a fairly large range of crops.

\section{SOURCES AND METHODS}

Population censuses in São Paulo were held every year since 1765 (Marcilio, 2000) in order to estimate the size of the male population subject to military draft for the frontier wars. The total area was divided in «vilas» (or «villages»), fairly large administrative units. Since 1798, the censuses started to report information on market sales per household. They registered quantity, revenue and location of total sales over the whole year (within the "village», outside the "village» and other) for twenty-three different products (sugar, coffee, corn, beans, pigs, rice, rum and minor products). It is thus also possible to compute total sales for each household. The source identifies households only with a progressive number within each «village».

The «market power» $(\mathbf{M})$ can be directly measured by the share of the household's sales over the sum of sales in the "village» (SHARE). The only proxy for size (S) is the amount of sales (TOTALSALES). Both variables are expected to be positive. The set of controls $\mathbf{X}$ includes a time trend (YEAR), dummies for product and «village», a dummy for households specializing in one product only (SPECIALIZED) and dummies for sales outside the village (SALESOUT) and in undisclosed locations (SALESOTHER). Unfortunately, it is impossible to trace households from one census to another, and thus to run a panel regression, which would have captured the unobservable features of the farms nicely, including the managerial skills of farmer. Therefore, regression 1) will be run with OLS in a log-log specification with heteroskedasticity-robust errors.

This paper relies on a data-base of 12,470 sales by 8,982 households over the period 1798-1835. The data were collected from the manuscript sources, the Maços de população, by several researchers - most notably Francisco Vidal Luna from the Universidade de São Paulo, who has been studying this source for the past 20 years (Vidal Luna, 1994, 1995, 1998 and 2002; Vidal Luna and Klein, 2001 and b, 2003 a and b; Vidal Luna and Klein, 2004). Unfortunately, the sample is not a truly random one. The distribution by product differs significantly from the composition of total output in 1836 (Muller, 1978) ${ }^{2}$. The sample under-represents corn and over-represents sugar, coffee and pigs. However, this composition might represent well the

2 The chi-square value is 210.6 , versus a test statistic (at 5 per cent for 17 classes) of 27.6 The three main commodities, coffee $(2,656)$, pigs $(2,516)$ and sugar $(2,337)$ account for about a 
sales, the variable of interest. Sugar and coffee were quintessential cash crops, while it was much more efficient to use corn to feed pigs for sale than to sell it on the market. The observations are also heavily concentrated in time (Figure 2) and space. They refer to twelve «villages» only —out of some fifty at the end of the period - and six of them account for almost nine out every ten observations ${ }^{3}$. They are well distributed in the area - two in the West Paulista, three in the Paraiba valley and one on the coast. Furthermore, the concentration may be a blessing in disguise, as the fairly high number of observations per «village» reduces the potential for bias from few outliers.

\section{A FIRST LOOK AT THE DATA}

Before running regression 1), it is important to show that there is something to explain -i.e. that households were paid different prices for the same good in the same «village». Figure 3 reports the distribution of price

FIGURE 2

NUMBER OF SALES TRANSACTIONS PER YEAR

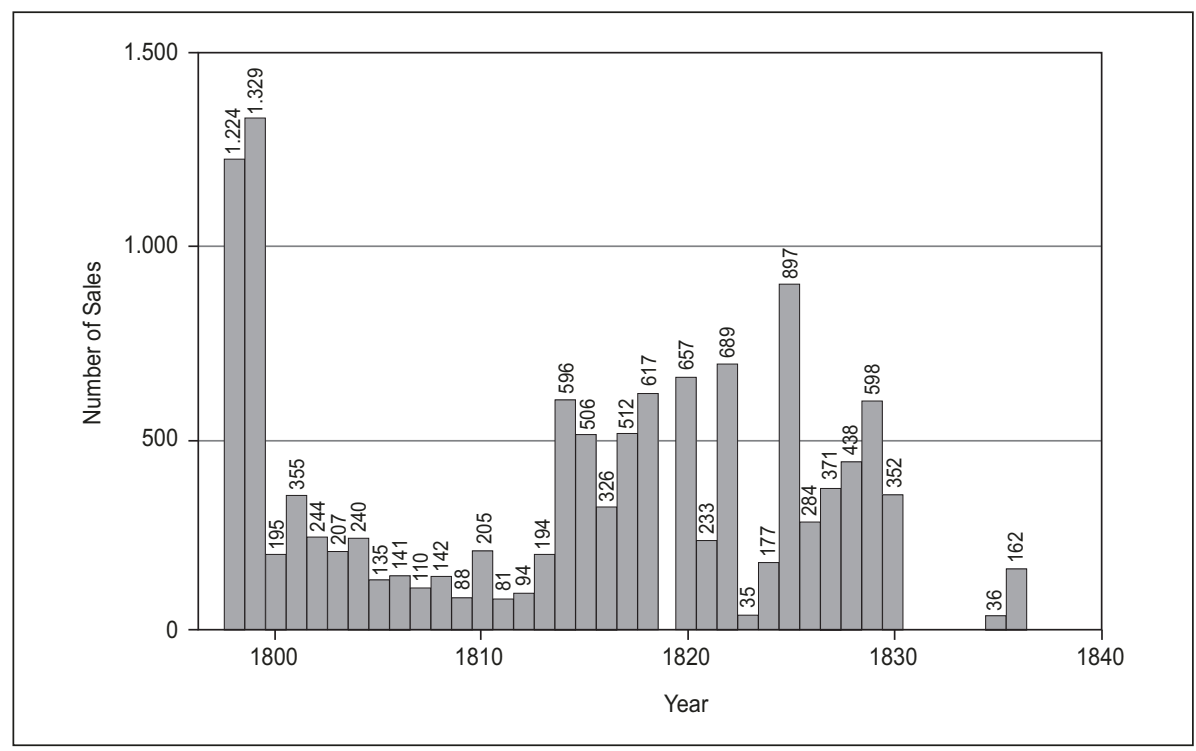

fifth of all observations. Other products are rum $(1,055)$, corn (763), oxen (563), tobacco (475), cotton (416), beans (337) and minor ones.

3 The two «villages» in the West Paulista are Mogi Mirim (2,218 observations) and Jundial $(1,614)$, the port is Sao Sebastiao $(1,898)$, while Guaratinguetà $(2,201)$, Areias $(1,953)$ and Lorena $(1,269)$ are in the Paraiba valley. 
FIGURE 3

KERNEL DISPERSION OF PRICES RELATIVE TO THE AVERAGE
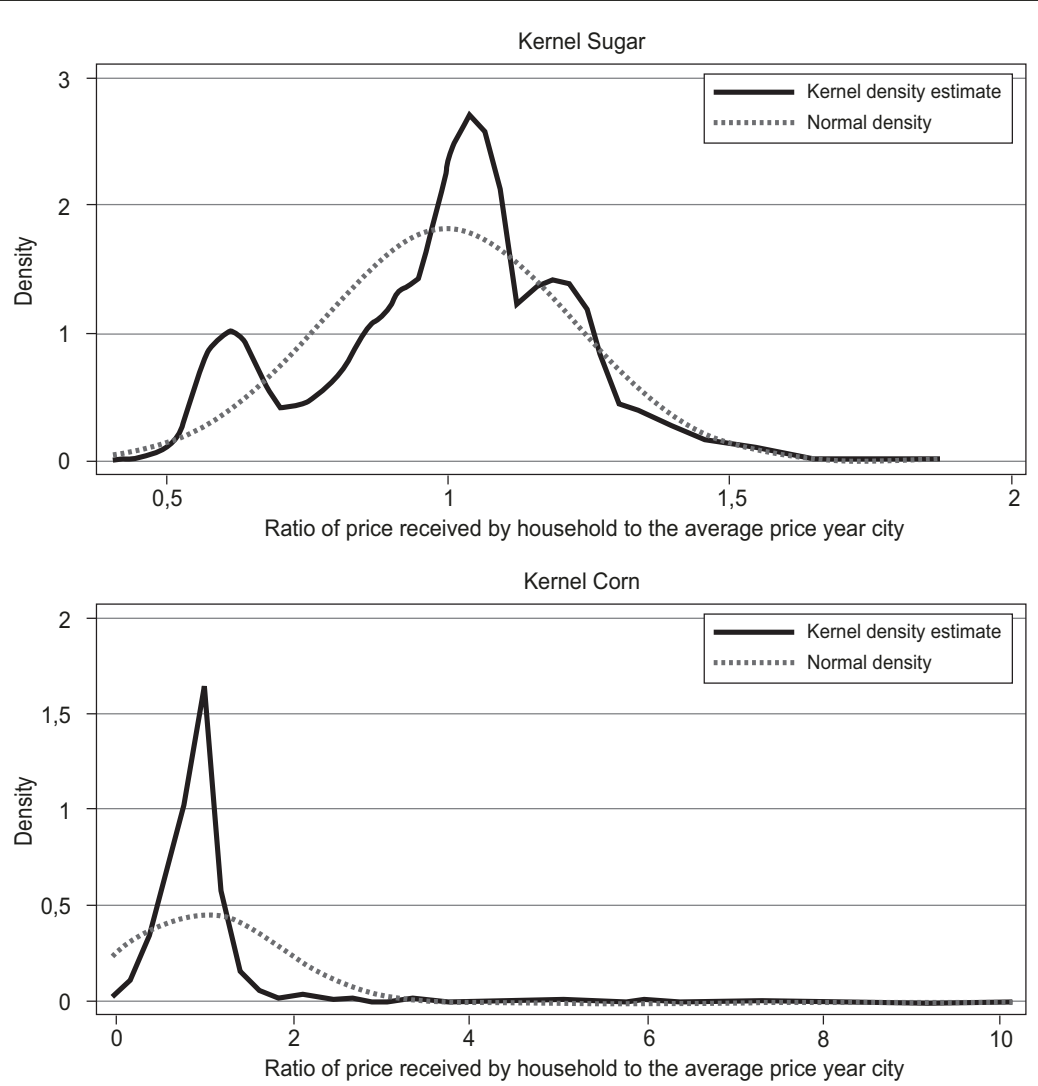

Kernel Coffee

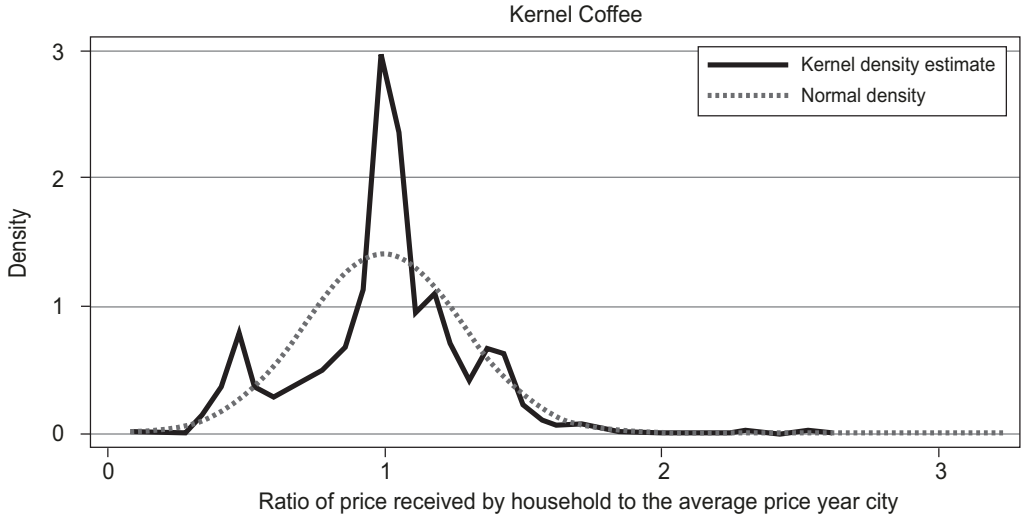


ratios (i.e. the dependent variable). The dispersion was small for corn (if one disregards some outliers, which may be spurious), and also for cotton, beans and rice (not shown). In contrast, prices were fairly dispersed for sugar and coffee - and in both cases a non-negligible number of households received a price about half the average.

As a boxplot graph shows (Figure 4), the quantity sold by product differed widely among households.

FIGURE 4

DISPERSION OF SALES BY HOUSEHOLDS, MAIN PRODUCTS

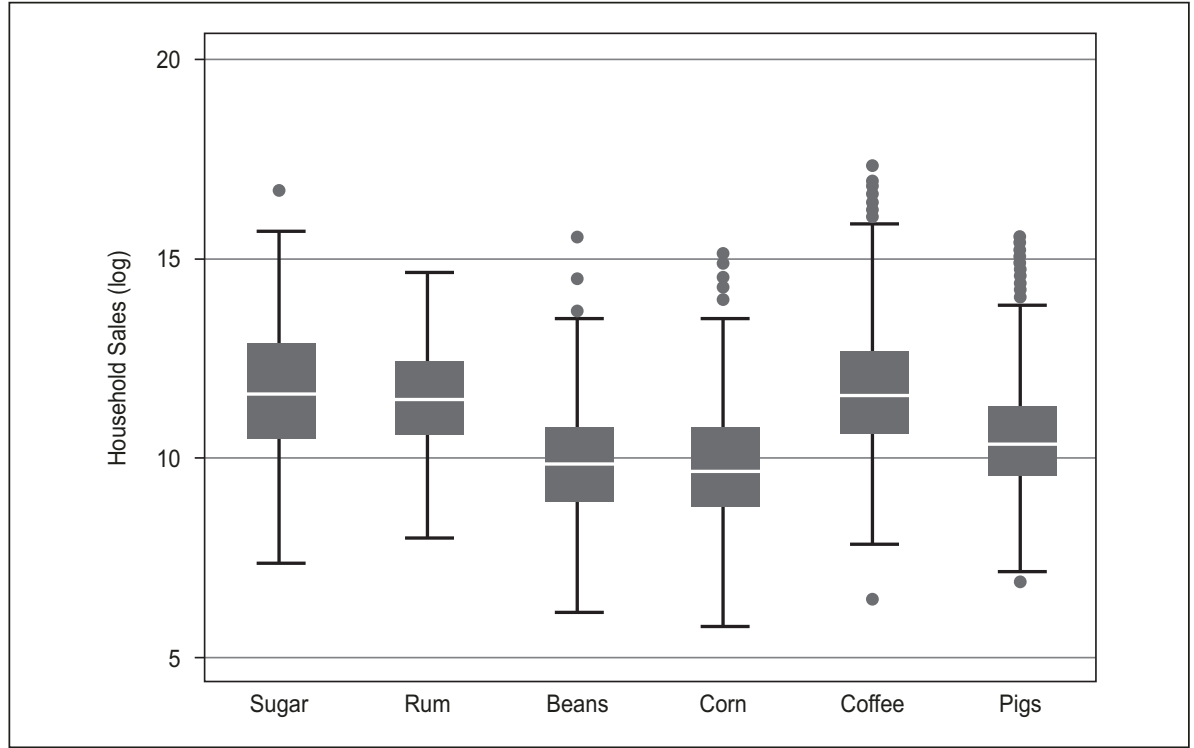

Differences in total sales per household were even greater. The median total sales over the whole sample amounted to some 45,000 reis - roughly $£ 8-9$ at the silver parity, equivalent, at average prices over the whole period, to 2.5 quintals of coffee or 4.4 quintals of sugar. But the sales of the top 1 per cent of farms were 1,400 times larger than those of the bottom 1 per cent, and the ratio was as high as 8.75 between the 75 per cent and 25 per cent quantiles. Furthermore, there is indirect evidence of market segmentation by size of farm, as posited in Figure 1. The average value of transactions outside the village was almost double those within the village ${ }^{4}$.

4 The figure is obtained from a regression with (log of) total sales as dependent variable, SALESIN, SALESOUT, YEAR and village and product dummies as independent ones. The loca- 
What about changes in time? As previously mentioned, conventional wisdom posits that average sales grew and that intra-household differences widened. These hypotheses can be tested by regressing logs of sales and the spread between the $25^{\text {th }}$ and $75^{\text {th }}$ quantiles against a time trend plus dummies for «village» and the location of sales as control (Table 1).

TABLE 1

CHANGES IN TIME

\begin{tabular}{|l|c|c|}
\hline & 1) & 2) \\
\hline Sugar & Sales & Interquantile 25-75 \\
\hline & $0.0152 * * *$ & $-0.00991 *$ \\
\hline Beans & $(5.49)$ & $(-2.35)$ \\
\hline & -0.00374 & 0.0131 \\
\hline Corn & $(-0.58)$ & $(1.20)$ \\
\hline & $0.0198^{* * * *}$ & -0.0145 \\
\hline Coffee & $(4.11)$ & $(-1.34)$ \\
\hline & $0.0620^{* * * *}$ & $0.0140 *$ \\
\hline Tobacco & $(16.30)$ & $(2.44)$ \\
\hline & $0.0135 * *$ & -0.00508 \\
\hline Pigs & $(2.94)$ & $(-0.81)$ \\
\hline & $0.0493 * * *$ & $0.0155^{* * *}$ \\
\hline Total sales & $(20.97)$ & $(7.16)$ \\
\hline & $0.0279 * * *$ & 0.000461 \\
\hline
\end{tabular}

t-statistics among brackets; * significant at 5 per cent; $* *$ significant at 1 per cent; $* *$ significant at 0.1 per cent.

Sources: see text.

As expected, sales by farm (column 1) grew, both for total and for each product except beans. Sales of coffee, the newest product, increased almost ten-fold, while total sales increased only by 2.8 times and those of sugar «only» by 75 per cent. However, as column 2) shows, intra-farm dispersion did increase for coffee and pigs only, while it decreased somewhat for sugar and was essentially trendless for total sales.

tion dummies are both highly significant. Ceteris paribus, sales within the «village» were 30 per cent lower than the reference group (SALESOTHER) and sales outside the village (SALESOUT) 60 per cent higher. 


\section{THE CAUSES OF PRICE DIFFERENTIALS: AN ECONOMETRIC ANALYSIS}

The previous Section has confirmed that i) prices differed and ii) households differed. Are the two features related as hypothesized? The results of running regression 1) for all households/all products are in Table $2^{5}$.

Column 1) reports a basic specification, without «village» and product dummies. The model performs fairly well. All variables, including SHARE and TOTALSALES, are highly significant, and this should rule out multicollinearity in spite of the high correlation between the two. The $\mathrm{R}^{2}$ is not impressive, but this is not really surprising, given the lack of controls. The $\mathrm{R}^{2}$ doubles by adding dummies for «village» and "product» (Column 2): eight out of twenty-three "product» dummies and five out of eleven «village» dummies are significant at 5 per cent or better. They clearly capture product and area specificity - and thus reduce the bias from non-randomness of the sample. Of course, they cannot capture differences within each «village» in environment (e.g. in soil quality) or in geographical location (most notably the distance from the main centers). Furthermore, the analysis cannot consider differences in timing of sales and in the quality of the product. However, the anecdotal evidence seems to rule out large differences between households at least in the former parameter. Agricultural techniques were uniformly primitive and there was no scientific selection of seeds or any other investment in research which could foster quality of the product (Buarque de Hollanda, 1966).

In spite of the residual variance, the results confirm the two key insights of the model. First, the larger estates were paid higher prices, and the difference was really important: the coefficient for TOTALSALES implies that prices at the 75 per cent quantile (as ranked by the variable itself) were ceteris paribus 80 per cent higher than at the 25 per cent quantile. Second, the effect of pure market power was substantial as well: the jump from a modest 10 per cent market share to near monopoly ( 90 per cent) increased the price received by about two thirds. Specialization in one product only paid quite well (prices a third higher), possibly by reducing transaction costs (e.g. for collecting information). As expected, the coefficient for SALESOUT is positive, although the implicit price difference with prices of sales in the village (about 15 per cent) is somewhat lower than expected ${ }^{6}$.

The coefficient of TIME implies that price differentials declined, ceteris paribus, by about 15 per cent over the whole period. In theory (cf. Figure 1),

5 The coefficients for village dummies and for (most) products are omitted for simplicity. Full data are available upon request. As an additional test, the regressions have also been estimated with robust errors by clusters (i.e. by "village»). The results stand, although the test statistics are slightly worse.

${ }^{6}$ The SALESOTHER variable is less representative as it includes a large number of missing observations. 


\begin{tabular}{|c|c|c|c|c|c|c|c|c|c|c|c|c|c|c|c|c|c|}
\hline$\widehat{\sigma}$ & $\begin{array}{l}\tilde{\Xi} \\
\dot{0}\end{array}$ & $\begin{array}{l}\hat{\sigma} \\
\stackrel{0}{e} \\
\dot{d}\end{array}$ & 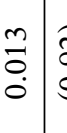 & 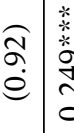 & 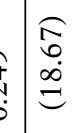 & 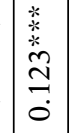 & $\mid \begin{array}{c}\hat{\sigma} \\
\tilde{e} \\
\stackrel{e}{e}\end{array}$ & $\mid$ & $\begin{array}{c}\widehat{\tilde{z}} \\
\stackrel{d}{d}\end{array}$ & 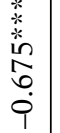 & $\mid \begin{array}{l}\widehat{\widehat{J}} \\
0 \\
0 \\
0 \\
\end{array}$ & & & & & & \\
\hline$\widehat{\infty}$ & $\begin{array}{l}0 \\
\stackrel{1}{1} \\
i \\
i\end{array}$ & $\begin{array}{l}0 \\
\stackrel{0}{0} \\
\dot{0} \\
i\end{array}$ & 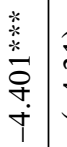 & 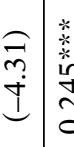 & 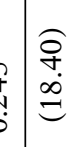 & $\mid \begin{array}{c}* \\
\vdots \\
\infty \\
o \\
0 \\
0 \\
0 \\
1 \\
1\end{array}$ & $\begin{array}{l}\widehat{\widetilde{\Omega}} \\
\hat{i} \\
\stackrel{\imath}{i}\end{array}$ & $\stackrel{n}{\beth}$ & \begin{tabular}{|c|c}
$\infty$ \\
$\stackrel{\infty}{+}$ \\
$\stackrel{\ominus}{e}$
\end{tabular} & $\begin{array}{l}0 \\
\infty \\
\stackrel{2}{0} \\
0\end{array}$ & 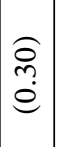 & 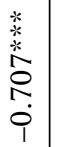 & $\begin{array}{l}\text { f } \\
\dot{I}\end{array}$ & 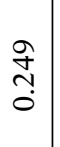 & $\begin{array}{l}\tilde{\Omega} \\
\stackrel{\Xi}{\Xi}\end{array}$ & 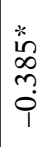 & 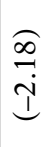 \\
\hline$\widehat{E}$ & 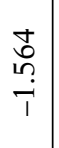 & \begin{tabular}{l|l}
$\stackrel{f}{f}$ \\
$\stackrel{1}{I}$ \\
I
\end{tabular} & 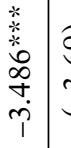 & 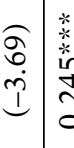 & 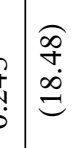 & 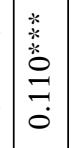 & 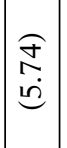 & \begin{tabular}{|c|}
$*$ \\
$\hat{N}$ \\
$\tilde{o}$ \\
0 \\
$\dot{0}$
\end{tabular} & $\mid \begin{array}{c}\widehat{d} \\
\stackrel{d}{d}\end{array}$ & $\begin{array}{l}m \\
\stackrel{n}{0} \\
\dot{q} \\
0\end{array}$ & 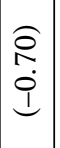 & & & & & & \\
\hline (6) & 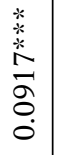 & $\begin{array}{l}\underset{\Im}{ \pm} \\
\stackrel{\vec{n}}{=}\end{array}$ & 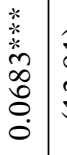 & 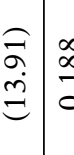 & 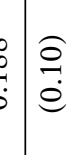 & 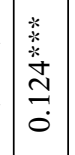 & 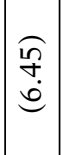 & $\begin{array}{c}\stackrel{*}{N} \\
\tilde{o} \\
0 \\
0\end{array}$ & 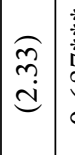 & 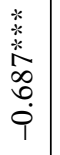 & $\mid \begin{array}{l}0 \\
o \\
\hat{0} \\
\dot{\varphi} \\
\end{array}$ & & & & & & \\
\hline हn & 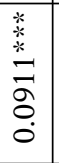 & 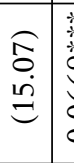 & 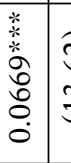 & 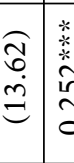 & 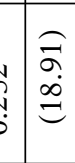 & 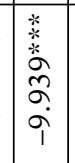 & $\begin{array}{l}\widehat{\mathbb{I}} \\
\mathfrak{I} \\
\mathbb{I}\end{array}$ & $\mid \begin{array}{l}2 \\
\sigma \\
0 \\
i \\
-1\end{array}$ & 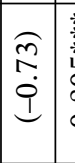 & 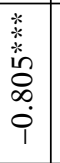 & $\mid \begin{array}{l}0 \\
\infty \\
\infty \\
\stackrel{I}{I} \\
\end{array}$ & & & & & & \\
\hline Ð & 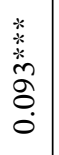 & $\begin{array}{l}\stackrel{\widehat{o}}{\circ} \\
\stackrel{\dot{m}}{=} \\
=\end{array}$ & 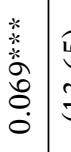 & 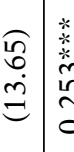 & $\begin{array}{l}\stackrel{\infty}{\infty} \\
\stackrel{\infty}{\infty} \\
\stackrel{\infty}{=}\end{array}$ & 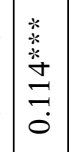 & \begin{tabular}{|c|}
$\widehat{\infty}$ \\
$\dot{\infty}$ \\
$\dot{v}$
\end{tabular} & $\begin{array}{l}* \\
\tilde{n} \\
\tilde{0} \\
0 \\
0\end{array}$ & $\stackrel{\vec{f}}{\stackrel{d}{d}}$ & 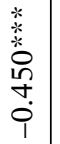 & 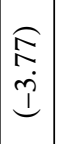 & $\begin{array}{l}\stackrel{*}{0} \\
\hat{o} \\
+ \\
\dot{\varphi} \\
1\end{array}$ & $\begin{array}{c}\widetilde{n} \\
\stackrel{n}{i} \\
\stackrel{I}{L}\end{array}$ & 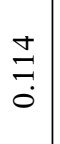 & $\begin{array}{c}\hat{\circ} \\
\stackrel{\circ}{e} \\
\stackrel{e}{e}\end{array}$ & 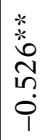 & $\begin{array}{l}\widehat{O} \\
\infty \\
i \\
\text { I }\end{array}$ \\
\hline ్ & 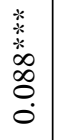 & $\begin{array}{l}\widehat{\Xi} \\
\stackrel{\Xi}{=}\end{array}$ & 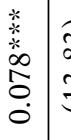 & 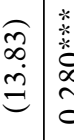 & 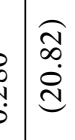 & 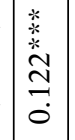 & 命 & 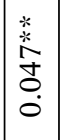 & 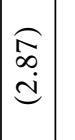 & & & & & & & & \\
\hline$\widehat{\widehat{Q}}$ & 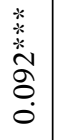 & $\begin{array}{l}\underset{I}{\stackrel{0}{n}} \\
\stackrel{5}{=}\end{array}$ & 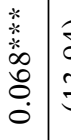 & 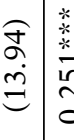 & 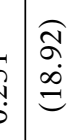 & 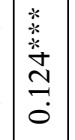 & 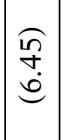 & 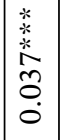 & $\underset{\widetilde{m}}{\stackrel{\overbrace{}}{d}}$ & 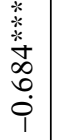 & $\left|\begin{array}{c}0 \\
0 \\
0 \\
0 \\
1\end{array}\right|$ & & & & & & \\
\hline$\Xi$ & 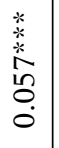 & $\begin{array}{l}\overparen{n} \\
\stackrel{0}{b} \\
\stackrel{\Xi}{=}\end{array}$ & 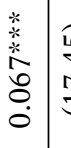 & 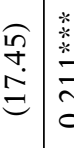 & 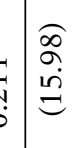 & 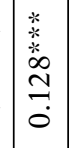 & I্ & 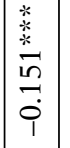 & \begin{tabular}{|c|}
$\stackrel{0}{0}$ \\
$\stackrel{m}{=}$ \\
$=$
\end{tabular} & 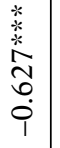 & 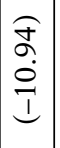 & & & & & & \\
\hline & 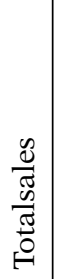 & & 总 & $\begin{array}{l}7 \\
0 \\
.5 \\
0 \\
0 \\
0 \\
0 \\
0\end{array}$ & 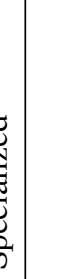 & $\begin{array}{c}\overrightarrow{0} \\
\bar{\infty} \\
\frac{\mathscr{D}}{\tilde{N}} \\
\tilde{n}\end{array}$ & & 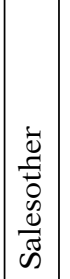 & & 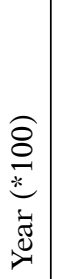 & & 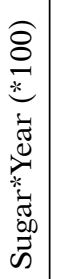 & & 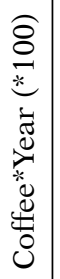 & & 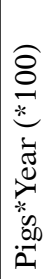 & \\
\hline
\end{tabular}




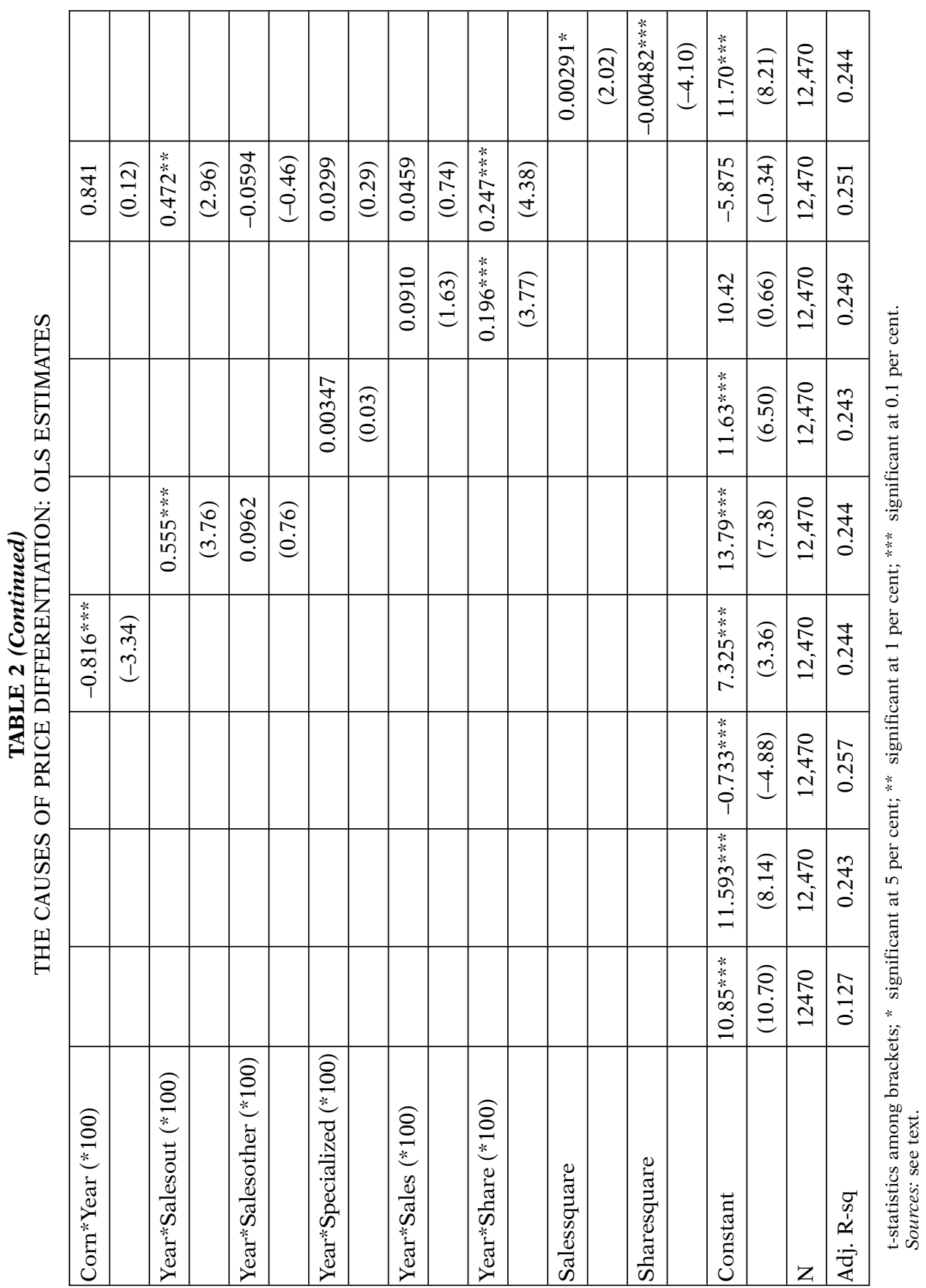


this trend might reflect declining market power, or a growing share of large farms, but also a general improvement in market efficiency, as reflecting improved circulation of information, or easier access to credit for all producers. The results of Table 1, column ii) strongly downplay the relevance of growing intra-household dispersion. Neither declining market power nor improving market efficiency is directly observable, but it is nevertheless possible to make some inferences by interacting key variables with time trend. As a starting point, Column 3 substitutes the time trend with year dummies to explore the timing of the change. Figure 5 shows the price ratios implicit in the significant year dummies. The concentration of low values in the second half of the end of the period tallies well with the anecdotal evidence about the development of infrastructures and market facilities in the first decades of the $19^{\text {th }}$ century, as the result of an alliance between merchants and the traditional landed elite (Kuznesof, 1980; see also Fragoso, 2002).

Column 4 shows that differences by product are sizeable but not huge. The total coefficient (the sum of YEAR and the product-specific interactions) ranges from a maximum of 1.26 for sugar to a minimum of 0.450 for coffee - corresponding respectively to a decrease by 35 per cent and by 15 per cent in price differentials over time, ceteris paribus. The positive and significant coefficient for the interaction between SALESOUT and the time trend (column 5) implies that efficiency gains affected sales within the village (the default variable) more. There was no significant trend in the positive effect of specialization (column 6) and, last but not least, market power was growing, ceteris paribus (Column 7). Column 8 lists all interactions

FIGURE 5

AVERAGE PRICE RATIOS BY YEAR

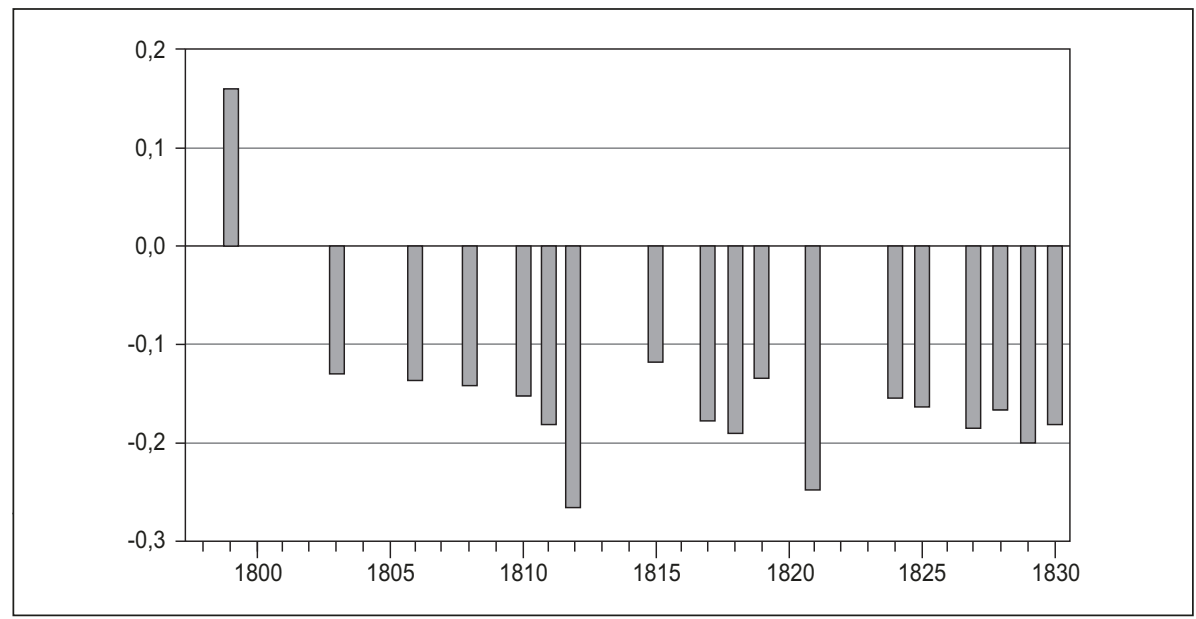


together, to test whether any of these conclusions are spurious. This is not the case: only one coefficient changes sign and becomes not significant. Thus, as a first approximation, one can conclude that the efficiency of the local markets was growing, at least for some products (notably pigs and coffee), but also that market power was somewhat on the rise.

The results so far suggest the existence of sizeable differences among products. Thus, Table 3 tests to what extent these differences extend to the key results of the whole model by re-running the basic specification (i.e. Table 2, column 2, of course omitting product dummies) for the four major products. In three cases out of four, the model performs well, with some difference in coefficients. The outlier is sugar: neither TOTALSALES nor SHARE is significant.

TABLE 3

THE CAUSES OF PRICE DIFFERENTIATION: PRODUCT ESTIMATES

\begin{tabular}{|l|c|c|c|c|}
\hline & Coffee & Corn & Sugar & Pigs \\
\hline Totalsales & $0.117 * * *$ & $0.038^{* * *}$ & -0.003 & $0.172 * * *$ \\
\hline & $(4.17)$ & $(6.08)$ & $(-0.33)$ & $(11.41)$ \\
\hline Share & $0.048 * *$ & $0.041 * * *$ & 0.004 & $0.141^{* * *}$ \\
\hline Specialization & $(2.24)$ & $(7.72)$ & $(0.57)$ & $(11.81)$ \\
\hline & $0.242 * * *$ & $0.098^{* * *}$ & $0.102 * * *$ & $0.345 * * *$ \\
\hline Salesout & $(4.65)$ & $(6.98)$ & $(8.18)$ & $(10.54)$ \\
\hline & 0.385 & $0.509 * * *$ & $0.052 * * *$ & $-0.230^{* *}$ \\
\hline Salesother & $(0.98)$ & $(33.12)$ & $(3.31)$ & $(-2.73)$ \\
\hline & 0.087 & $0.361 * * *$ & -0.011 & -0.049 \\
\hline Year $(* 100)$ & $(1.43)$ & $(24.87)$ & $(-0.54)$ & $(-1.28)$ \\
\hline & $-1.126 * * *$ & $-0.555 * * *$ & 0.141 & $-1.957 * * *$ \\
\hline Constant & $(-3.82)$ & $(-6.55)$ & $(1.71)$ & $(-10.15)$ \\
\hline & $19.320 * * *$ & $9.821 * * *$ & -2.538 & $34.135 * * *$ \\
\hline N & $(3.7)$ & $(6.43)$ & $(-1.67)$ & $(9.86)$ \\
\hline Adj. R-sq & 662 & 2,656 & 2,268 & 2,516 \\
\hline & 0.177 & 0.4935 & 0.0405 & 0.366 \\
\hline
\end{tabular}

t-statistics in brackets; * significant at 5 per cent; ** significant at 1 per cent; *** significant at 0.1 per cent.

Sources: see text. 
The discussion so far assumes the effect of variables to have been linear -i.e. that an increase in market share from 10 to 20 per cent affected price differentials as much as one from 70 per cent to 80 per cent. One might suspect this assumption not to be true. The standard approach to the issue, the addition of adding squared terms, does not perform well (Table 2, column 9). This result does not rule out a more complex non-linear pattern. It can be investigated by running quantile regressions (Konker-Basset, 1978; Konker, 2005) ${ }^{7}$.

As usual, results are reported plotting the variation of each coefficient by quantile of the dependent variable, surrounded by their (bootstrapped) 5 per cent confidence interval. Figure 6 also reports, for comparison, the OLS estimates of Table 2 and their confidence interval. The most interesting result is the opposite pattern between the two key variables, SHARE and TOTALSALES. The effect of the latter is very strong at low prices, up to the 40 per cent quantile, but it fades away at higher prices, whilst that of

FIGURE 6

QUANTILE REGRESSIONS
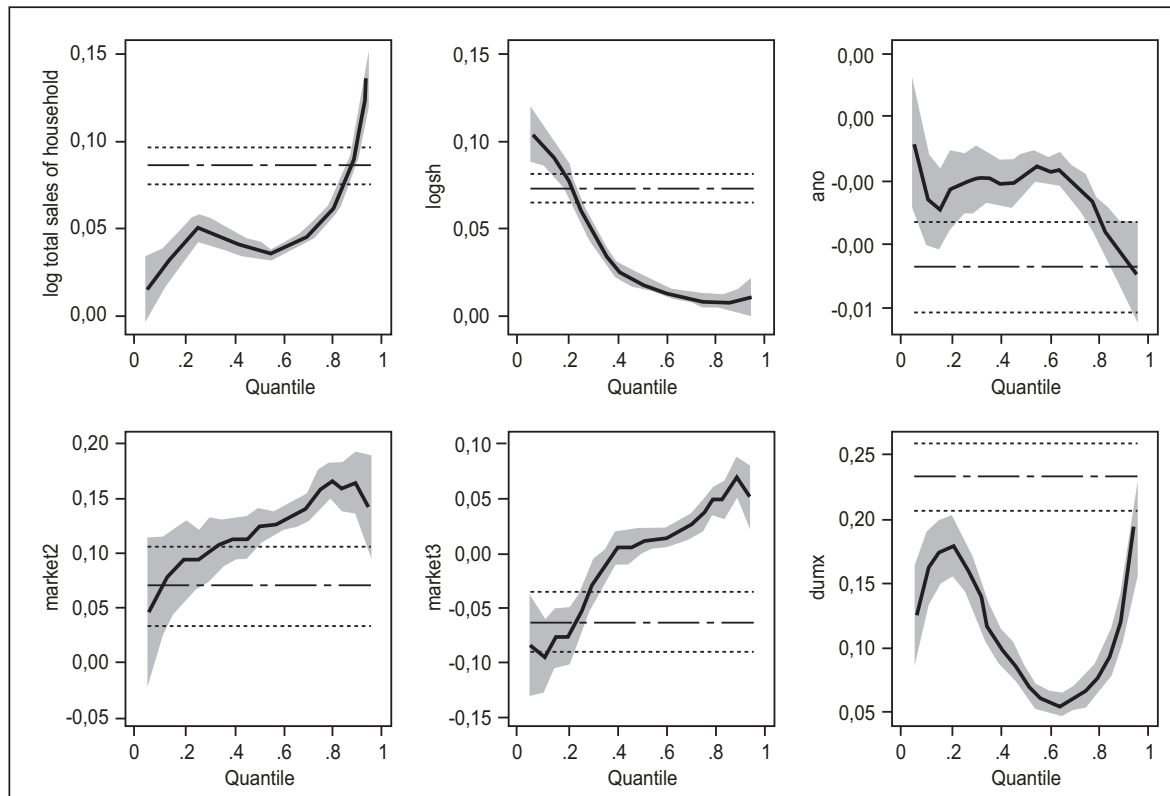

7 The quantile regressions use specification of column 2) in Table 2, substituting the village dummies with dummies for three major regions. The results for the extreme quantiles are less representative as they include a number of outliers. 
TOTALSALES -i.e., in our interpretation, of farm size, is strongest at very high prices. The simple coefficient of correlation between SHARE and TOTALSALES is about 0.65 , so the two effects did not cumulate fully. A high market share helped to push (relative) prices towards the average, but it does not explain the very high prices. These latter reflected mostly the size of the farm, but their key advantage was not the domination of local market. This interpretation is supported also by results for SALESOUT (sales outside the village) and YEAR (market efficiency): in both cases, the coefficients are higher for the upper tail of the distribution. In both cases, the OLS coefficients appear to capture mostly effects at fairly high prices, which large farms were more likely to obtain. The effect of specialization is highly non-linear and smaller than that suggested by the OLS regression.

\section{CONCLUSION}

The paper has aimed to answer a simple question: did power on the local market, as measured by the share on total sales, help to get higher prices in early $19^{\text {th }}$ century São Paulo? The answer is tentatively positive: some market power did exist, and may even have been growing in time. However, it helped avoiding being squeezed more than getting a high price. Arguably, in order to receive really high prices, access to information and credit, as proxied by farm size, was more important than power on the local market. The conditions in the area were improving from this point of view as it became more settled. It seems unlikely that the results are spurious, in spite of the limitations of the data and of the available set of explicative variables.

To what extent does this conclusion hold true for other traditional agricultural markets? Without comparable data, one can only speculate. As mentioned, São Paulo featured a mix of plantation and small family farms, a sort of mixed or intermediate slave economy - to some extent similar to the Southern United States before the Civil War. A priori, these «mixed» cases seem the most likely to feature price differentials and thus to yield meaningful results with this approach. In contrast, price differentials are likely to have been smaller, or nonexistent, in more homogeneous agrarian societies. This hypothesis holds true almost by definition where small household farms prevailed, as in the American Midwest. It also seems plausible where a small number of large estates dominated a well organized market, as in the West Indies.

\section{REFERENCES}

BATEMAN, V. (2007): «The evolution of markets in early modern Europe 1350-1800: a study of grain prices», University of Oxford Department of Economics Discussion paper series, 350. 
Buaroue de Hollanda, S. (1966): «Movimentos da Populacao em São Paulo no Século XVIII», Revista de Estudos Brasileiros, 1.

Findlay, R., and O'Rourke, K. H. (2007): Power and Plenty: Trade, War, and the World Economy in the Second Millennium, Princeton University Press.

Fragoso, João (2002): «Mercados e negociantes imperiais: um ensaio sobre a economia do império Português (Séculos XVII e XIX)», História: Questões \& Debates, 36, pp. 99-127.

JACKS, D. (2005): «Intra - and international commodity market integration in the Atlantic economy», Explorations in economic history, 42 n 3 (July 2005), pp. 381413.

Konker, R. (2005): Quantile Regression, Cambridge University Press: Cambridge.

Konker, R., and Bassett, G. (1978): «Regression Quantiles», Econometrica, 46, pp. 33-50.

KuZNESOF, E. A. (1980): «The role of merchants in the economic development of São Paulo», Hispanic American Historical Review, 60, pp. 571-592.

LunA, F. V. (1994): "População e atividades econômicas em Areias (1817-1836)», Revista Estudos Econômicos, São Paulo, IPE-USP, 24, pp. 433-463.

- (1995): «Areias: Posse de Escravos e Atividades Econômicas (1817-1836)», Caderno Nehd, São Paulo, 2, FEA/USP.

- (1998): «São Paulo: População, Atividades e Posse de Escravos em vinte e cinco localidades (1777-1829)», Revista Estudos Econômicos, São Paulo, 28, pp. 99-169.

- (2002): "Observações sobre os dados de produção apresentados por Müller», Boletim de História Demográfica, 9.

LunA, F. V., and KLEIN, H. S. (2001a): «Nota a respeito de medidas de grãos utilizadas no período colonial e as dificuldades para a conversão ao sistema métrico», Boletim de História Demográfica, 8.

- (2001b): «Observações sobre Preços Agrícolas em São Paulo (1798/1836)», Boletim de História Demográfica, 8.

- (2003a): Slavery and the economy of São Paulo, Stanford: Stanford University Press.

- (2003b): «African Slavery in the Production of Subsistence Crops; the Case of São Paulo in the Nineteenth Century», in Eltis, D.; Lewis, F. D., and Sokoloff, K. L., Slavery in the Development of the Americas, Cambridge: Cambridge University Press, pp. 120-149.

- (2004): «Slave Economy and Society in Minas Gerais and São Paulo, Brazil, in 1830», Journal of Latin American Studies, 36, pp. 1-28.

MARCILIO, M. L. (2000): Crescimento demografico e evolucao agraria paulista, 1700-1836, São Paulo: Editora Hucitec: Edusp.

McCloskey, D., and Nash, J. (1984): «Corn at Interest», American Economic Review, 74, pp. 174-187.

Müller, D. P. (1978): Ensaio d'um quadro estatístico da província de São Paulo: Ordenado pelas leis provinciais de 11 de abril de 1836 e 10 de maro de 1837, Coleção Paulística, vol. 11, São Paulo: Governo do Estado de São Paulo.

Prado, J. R., Caio (1942): Formação do Brasil Contemporâneo, Editora Brasiliense.

Petrone, M. T. S. (1967): A lavoura canavieira em São Paulo, Difusão Européia do Livro.

RothenBerg, W. (1992): From market-places to a market economy, Chicago-London: University of Chicago Press.

Schroeter, J.; AzZAN, A., and Zhang, M. (2000): «Measuring market power in bilateral oligopoly: the wholesale market for beef», Southern economic journal, 66, pp. 526-547. 
Shiue, C. H., and Keller, W. (2007): «Markets in China and Europe on the eve of the Industrial revolution», American Economic Review, 97, pp. 1189-1216.

Sexton, R., and Lavoie, N. (2001): «Food processing and distribution: an industrial organization approach», in B. GARDNER and G. RAUSSER (eds.), Handbook of agricultural economics, vol. I B, pp. 864-932, Amsterdam Elsevier.

STUDER, R. (2008): "India and the great divergence. Assessing the efficiency of grain markets in $18^{\text {th }}$ and $19^{\text {th }}$ century India», Journal of Economic History, 68, pp. 393-437.

WOLHGENANT, M. (2001): «Marketing margins: empirical analysis», in B. GARDNER and G. RAUSSER (eds.), Handbook of agricultural economics, vol. I B, pp. 933-970, Amsterdam Elsevier. 